\title{
Impact of External Debt on Nigeria's Foreign Reserve Portfolios
}

\author{
Peter E. Ayunku' \\ Dumani Markjackson ${ }^{2 \rtimes}$ (D)
}

'Department of Banking and Finance, Niger Delta University, Wilberforce Island, Bayelsa State, Nigeria. Email:peterayunku@yahoo.com Tel: +2348037957234

${ }^{2}$ Department of Banking and Finance, Federal Polytechnic, Ekowe, Tenagoa, Bayelsa State, Nigeria.

Email:abinami1990@gmail.com Tel:+2347089383905

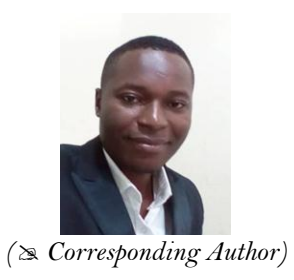

Abstract

This study examines the impact of external debt and external debt servicing on the international reserves of Nigeria. The theoretical underpinning of the study was anchored on dual gap theory and the self-insurance theory of external reserves. The after effect research design was adopted to examine the components of the study in retrospect. Historical data spanning 1981 to 2018 was collated from the World Development indicators and analyzed using the error correction mechanism as the unit of analyses and estimated employing the least square technique. The empirical findings indicate that external debt stock exert a negative and statistically significant impact on Nigeria's foreign exchange reserve portfolios. It further emerged that external debt service payments exert a positive but statistically insignificant impact on the international reserves of Nigeria. The study concludes that external debt stock and external debt service payments has no significant impact on the international reserve portfolios of Nigeria. The study recommends that, the fiscal managers of Nigeria should exercise cushion in external borrowing in order to ensure that concomitant external debt service payments does not deplete the international reserves of the country.

Keywords: External debt, External debt servicing, International reserves, Dual gap theory, Self-insurance theory, Nigeria. JEL Classification: H69, F31.

Citation | Peter E. Ayunku; Dumani Markjackson (2020). Impact of External Debt on Nigeria's Foreign Reserve Portfolios. Asian Journal of Economics and Empirical Research, 7(1): 1-7.

History:

Received: 8 November 2019

Revised: 11 December 2019

Accepted: 15 January 2020

Published: 3 February 2020

Licensed: This work is licensed under a Creative Commons

Attribution 3.0 License $(\mathrm{cc}) \mathbf{E}$

Publisher: Asian Online Journal Publishing Group
Acknowledgement: Both authors contributed to the conception and design of the study.

Funding: This study received no specific financial support

Competing Interests: The authors declare that they have no conflict of interests.

Transparency: The authors confirm that the manuscript is an honest, accurate, and transparent account of the study was reported; that no vital features of the study have been omitted; and that any discrepancies from the study as planned have been explained.

Ethical: This study follows all ethical practices during writing.

\section{Contents}

1. Introduction

2. Theoretical Framework

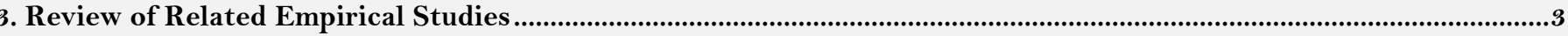

4. Methodology.

5. Econometric Results

6. Conclusion

References. 


\section{Contribution of this paper to the literature}

This study contributes to existing literature by examining the impact of external debt and external debt servicing on the international reserves of Nigeria.

\section{Introduction}

The funding challenges of developing countries are not alien to policy makers, researchers and academics. It is widely held that developing nations are constrained of sufficient funds to build basic infrastructure that would set the pace for capital formation and sustainable growth (Ayadi and Ayadi, 2008; Saheed et al., 2015; Rahaj, 2018). This implies that tax revenue, crude oil proceeds and proceeds from other natural endowments which form the bulk of government revenue in developing countries are inadequate to stimulate sustainable growth. This is as a result of their inability to build adequate collection structures, tax base and acute volatility of commodity prices. Faced with shortfalls in revenue and the need to increase investment in public works, developing countries engage in deficit spending to bridge the gap in funding public expenditure. Central to this axiom is the beliefs that increase in public expenditure cultivate and stimulate the national productivity possibility curve outwards. The origin of this theory can be traced to Wagner's Law of increasing state activity of 1883 which averred that the size of economic development of a nation is directly a function of the size of public spending of that nation (Magazzino et al., 2015; Yoshito, 2015).

Nigeria has consequently been engaging in deficit spending as anchor to capital formation and sustainable output growth. Plethora of studies has established that internal or external debt, when applied wholly on public works and infrastructure has the capacity to stimulate the economic wellbeing of a nation (Oshikoya, 1989; Asogwa et al., 2018). According to Soludo (2013) public debt is needed to elevate and spur the size of aggregate investment and circumvent funding constraints of government budget in order cultivate sustainable growth and the GDP per capita of the nation. Records show that the fall in commodity prices in 1978 pressured the federal government to borrow from overseas (external debt) due to its dwindling foreign exchange earnings from crude oil to meet her many public works and projects in order to better the lots of the people (Ndubuisi, 2017; Asogwa et al., 2018; Rahaj, 2018). However, records indicate that Nigeria used external loans to finance its first plan of development in 1962 (Oshikoya, 1989). Public expenditure funding over the years have not changed significantly as government has been using borrowed funds to finance its expenditure plan due to revenue shortfalls from tax and oil.

The use of public debt in bridging the revenue shortfalls of the government is additionally creating a huge economic problem for countries as the debt figures continue to spiral. According to the Debt Management Office (2019) Nigeria's foreign debt stands at 27.162 billion USD, while local debt stood at 56.72 billion USD as at June 30, 2019. This calls for concern even as it has been averred that much of public debt in Nigeria have been misapplied due to indiscipline and thus fails to yield the anticipated results and reasons for the facility (Senibi et al., 2016; Rahaj, 2018). Thus, making Nigeria to be a highly indebted nation with poor public infrastructure, per capita income and national productivity.

The exponetial increase in public expenditure enabled by external borrowings creates a huge burden on the nation. This is because the spiraling foreign debt stock poses a huge debt servicing obligation which has over the years gulped a gigantic sum of the national budget; thus, impeding national productivity possibilities (Johansson, 2010). The repayment of the external debt stock and interest amount (otherwise called debt servicing) exert an enormous burden on the internatonal reserves of a nation due to the fact that the repayments are made in foreign currency. This implies that external settlements are sourced from the international reserves of the sovereign nation. They are also used to influence the exchange rate of the local currency. International reserves therefore, serve the purpose of preserving capital and provision of liquidity to meet the foreign exchange needs of the people (Tule et al., 2015). Thus, further serving as the store of the international value of the national currency (Ito and McCauley, 2019) and other negative external shocks on the economy (Espinoza and Winant, 2014). In fact, it is averred that international reserves is a major pointer to the debtor nation's ability to pay back the principal amount and interest on the external debt (Onwuka and Igwezea, 2014).

Although external debt could be a reproductive stimulant in a well cultured system with fiscal discipline; however, this is yet to be seen in Nigeria owing to fiscal indiscipline and financial corruption. Consequently, the twin attacks on the international reserves of the nation via concormitant debt servicing and foreign exchange for importation stand to drain the reserves without a corresponding increase in earnings. Futher to this, economic theory holds that increasing external debt exposes a nation to high risk and that increasing foreign exchange reserves reduces the exposure level of a nation (Mansour, 2013). However, debt servcing obligations stand to reduce the international reserve holdings of the nation. Given the spiraling external debt position of the nation; it is important to understand the dynamics of these variables in Nigeria. This tellingly makes it plausible to use econometric techniques to interrogate the interplay between external debt stock, debt servicing and international reserves. This is significant on sundry levels; (1) available extant studies are scant; (2) lately due to dwindling prices of primary commodities, developing nations are rapt on deficit financing via external debts, thus increasing the debt servicing obligation and depleting the international reserves of developing sovereign nations. Thus, it is imperative to study this phenomenon and contribute to the body of knowledge on external debt and foreign exchange reserves in Nigeria.

\section{Theoretical Framework}

The theoretical under pinning of this study are the dual gap theory of debt and the self-insurance theory of external reserves.

One common attribute of developing nations is their inability to accumulate aggregate savings large enough for investment in public works and infrastructure that would stimulate capital formation and national productivity. Their inability to enhance aggregate investment due to low aggregate savings arising from fiscal indiscipline creates a puzzle on how best to raise funds for public spending. This creates an obvious gap in savings and investment which needs to be bridged. In other words, the shortfall needs to be filled to increase public capital. Consequent on these, the dual gap theory of 1966 propagated by Chenery states that lack of adequate domestic 
savings creates a gap, and that the need to increase aggregate public spending in form of investments leads to foreign borrowings (Chenery and Strout, 1966; Rahaj, 2018).

Self-insurance entails setting aside funds in order to mitigate possible unfortunate circumstances. It simply means maintaining a buffer stock to intervene on external shocks. Thus, the self-insurance theory of external reserves holds that nations should accumulate international reserves in the form of hard foreign currency, bank deposits, near money instruments in foreign denominations like treasury bills and certificates, gold holdings and special drawing rights. The theory posit that this would help the country to mitigate external shocks and serve as a buffer stock to intervene on the foreign exchange rate of a country (Akamobi and Ugwunna, 2017). Thus, the theory holds that reserve accumulation help ensure that the price of foreign to that of the local currency other time is stable.

\section{Review of Related Empirical Studies}

Several empirical studies have been carried out on external debt and foerign exchange reserves. However, there are scant studies on external debt and foreign exchange reserves in Nigeria. This section presents review of related empirical studies on the major parameters of the study.

Nwachukwu et al. (2016) examined the impact of exchange rate on Nigeria's international reserves using daily data spanning 2014 to 2015 . The data was estimated using the threshold vector error correction technique. The results indicate that the coefficient of the error correction term was statistically insignificant. The results further indicate that the adjustment flow in the variables flow from international reserves to exchange rate in Nigeria.

Saheed et al. (2015) examined the effect external debt has on foreign exchange rate in Nigeria. the study used foreign debt stock, debt service payment and foreign reserves as the explanatory variables, while foreign exchange rate was used as the explained variable otherwise known as the dependent variable. Time series data was collated and estimated employing the ordinary least square technique. The results show that all the explanatory variables have statistically significant impact on foreign exchange rate in Nigeria.

Senibi et al. (2016) investigated the impact of public debt on foreign exchange reserves in Nigeria. Historical data spanning 1981 to 2013 was collated and analyzed using Fully Modified Ordinary Least Square method of estimation. The estimates indicate that public debt has a positive statistical impact on foreign exchange reserves in Nigeria.

Onwuka and Igwezea (2014) studied the impact of external reserves and external debt on Nigeria's exchange rate to the United State dollar. To achieve this, the study assumed that exchange rate is a function of external reserves and external debt in Nigeria. Time series data spanning 1981 to 2010 was collated. A multiple regression model was built and estimated using the ordinary least square technique. The results indicate the existence of a positive nexus between foreign reserves and external debt on foreign exchange rate in Nigeria.

Ugwuegbe et al. (2016) investigated the impact of foreign debt and foreign grant on economic growth in Nigeria, using time series data spanning 1980 to 2013. The data was estimated using the error correction technique following the least square technique. The empirical results indicate the existence of a significant linear nexus between external debt and national output. Results further show that foreign grant exert a positive impact on economic growth at an insignificant rate.

Akpan (2016) examined the impact of international reserves of Nigeria on gross domestic product, inflation, FOREX, unemployment, investment, foreign public debt and total trade. Time series data spanning 2004 to 2010 was collated for the analyses and estimation. The study employed the least square technique for the estimation. The results indicate that gross domestic product and exchange rate exert a positive and significant impact on foreign exchange reserves. Other results indicate that inflation, investment and total trade has a positive impact on external reserves at an insignificant rate. The results for external debt and unemployment rate were found to bear negative and insignificant impact on the external reserves of Nigeria.

Asogwa et al. (2018) assessed the impact of foreign debts and foreign exchange reserves on economic growth in Nigeria. The study assumed that gross domestic product is a function of Nigeria's external debt stock and reserves. Time series data covering 2007 to 2016 was estimated employing the ordinary least square technique to empirically explain the changes in economic growth that is caused by the explanatory indicators of the study. It emerged that foreign debt service payments exert an insignificant indirect impact on output growth, while external debt amount had a direct impact on economic growth at an insignificant level.

The study by Ndubuisi (2017) examined foreign debt service payment, external debt, international reserves, and exchange rate on real gross domestic product in Nigeria. Historical data spanning 1985 to 2015 was collated and analyzed using the error correction technique. The results showed that foreign debt service payments exert a negative and insignificant impact on output growth in Nigeria. Eternal debt was found to have a linear and statistically significant impact economic growth in Nigeria. International reserves and exchange rate which were used as control variables had a statistically significant impact the national productivity of Nigeria.

Nwanne and Eze (2015) examined the nexus between external debt stock, external debt service payment and foreign exchange rate in Nigeria. Time series data spanning 32 years, 1981 to 2013 was collated and analyzed using the Johansson cointegration test, which established the existence of long run equilibrium relationship. The ordinary least technique was employed to determine the direct and magnitude of the relationship. The results indicate that external debt stock has a positive relationship with foreign exchange rate, while external debt service payment exerted a negative effect on exchange rate in Nigeria.

Anidiobu and Okolie (2016) carried out a response study on external debt and exchange rate volatility in Nigeria. The study specifically set out to ascertain if external debt, external debt service payment and balance of trade has a positive and or significant relationship exist between these explanatory variables and exchange rate. Historical data covering 1986 to 2013 and estimated using the ordinary least square technique. The study found that the external debt stock exerted a positive but insignificant effect on exchange rate. It also emerged that external debt service payment has a negative and insignificant influence on exchange rate. Balance of trade however, indicated that the variable has a positive and significant impact on exchange rate in Nigeria. 
Using the granger causality test and ordinary least square technique, Draz and Ahmad (2015) investigated the influence of foreign debt and crude oil prices on exchange rates in Pakistan. Time series data spanning 1965 to 2009 was collated for the analyses and estimation. The test results revealed that foreign debt exerted a statistically significant impact FOREX. It also emerge that world crude oil prices bear an insignificant impact on FOREX in Pakistan.

Essien et al. (2016) investigated the effect of domestic and foreign debt on lending interest rates, consumer price index and national output in Nigeria. The study used secondary time series data spanning 1970 to 2014. A VAR model was built and the estimates indicate that external shocks to the lag of foreign debt stock raised the lending interest rate. It further emerged that aggregate public debt exerted a statistically significant influence on consumer price index and national output in Nigeria.

The study by Abdullahi et al. (2015) seeks to ascertain the determinant of external debt accumulation in Nigeria. Historical data covering 1980 to 2013 was collated and estimated using ARDL. The study hypothesized that exchange rate, savings, lending interest rate and budget deficit as the determinants of foreign debt accumulation in Nigeria. The study found that the independent variables of the study have a significant impact on external debt in Nigeria in the long term; however, the adjustment speed was found to be weak in the short term.

Kouladoum (2018) investigated the impact of foreign debt stock on real foreign exchange rate in Chad. The independent variables of the study are - external debt stock, external debt service payments, public spending, aggregate public investment, broad money supply and the degree of trade openness, whereas the endogenous variable of the study is real foreign exchange rate. Historical data from 1975 to 2014 was collated and estimated using GMM. The results indicate that foreign debt stock exerts a positive and significant impact on the dependent variable at the $5 \%$ threshold. Aggregate investment and government spending was found to be have a statistically insignificant negative impact on FOREX. Other results indicate that broad money supply has a linear but insignificant influence, while debt service payment exerted a statistically significant nonlinear impact on real exchange rate in Chad.

Eva et al. (2015) examined the determinants of external debt stock in Malaysia. The study hypothesized gross domestic product, real interest rate, consumer price index and broad money supply as determinants of foreign debt in Malaysia. Time series data spanning 1970 to 2013 was collated for the empirical analysis. The ordinary least square technique and variance decomposition was used to estimate that data. Findings from the study show that there is a long term equilibrium relationship between the independent variables and the dependent measure of the study. Furthermore, the study found that real interest rate has a short term nexus with external debt. Also, the variance analysis indicate that real interest rate was more potent exogenous variable than the other factors, whereas, consumer price index was found to be more potent endogenous variable amongst the variables of the study.

Olomola and Ajayi (2018) investigated the factors affecting the foreign exchange reserves in West African states. The study hypothesized population, constant GDP per capita, constant exports receipts, percentage of imports to GDP and nominal exchange rate. Historical data was collated for the estimation using the ordinary least square technique. It emerged that population, GDP per capita, export receipts exert positive and significant impact on international reserves. The estimates further show that the ratio of import to GDP and nominal exchange rate exerts a negative but significant impact on foreign exchange reserves.

Similarly, Osigwe et al. (2015) appraised the factors determining external reserve portfolios of Nigeria. The study theorized that the reserve portfolio of the country is determined by foreign exchange rate, crude oil exports, foreign direct inflows, real national output, lending interest rate, consumer price index and non-oil exports. To avoid spurious results, the Augmented Dickey Fuller test to stabilize the series. The ordinary least square was used to estimate the data. The estimates indicate that national output, oil export and foreign direct investments have a linear and significant influence on foreign reserves. Exchange rate and inflation were found to be negative and significant determinants of international reserves. Furthermore, lending interest was found to be nonlinear and statistically insignificant influence on external reserves. The study concludes that GDP, oil exports and foreign capital inflow as the determinants of international reserves in Nigeria.

In another study on the determinants of international reserve holdings of Nigeria by Akamobi and Ugwunna (2017). The authors holds that the factors affecting Nigeria's international reserves are real national income, inflation rate, lending interest rate, nominal foreign exchange rate, crude oil prices and domestic credit in the economy. They collated time series data spanning 1970 to 2013 to empirically ascertain their theoretical position. In order to absolve the long run and short term dynamics established using the cointegration test, the error correction technique was employed. The estimates from the analytical tool show that international crude oil prices and the supply of credit as the key determinants of Nigeria's external reserves. However, the other independent variables were found to be determinants of external reserves in the long run, meaning the effect they exert reserve accumulation is built over a long period of time.

\section{Methodology}

\subsection{Research Design}

The study adopted the after effect research design (also known as the ex post facto research design). The choice of this design is anchored on the fact that the researcher has no direct or indirect control over the behaviour of the phenomenon in the past. Thus, the study used historical data to mimic and investigate the interaction of these variables spanning 1981 to 2018 , a 37 years period in retrospect.

\subsection{Source and Nature of Data}

Data for the study was collated from the World Development Indicators. This implies that the data for the study was collated from a secondary source. The nature of data collated for the study is time series data covering 1981 to 2018. 


\subsection{Model Specification}

The model for this study is built following closely to extant literature on external debt and international reserves reviewed in this study. However, the study introduced exchange rate and lending interest rate as control to enable the interaction between the dependent and independent variables of the study.

The functional relationship between the dependent variable and the explanatory variables is expressed as: ExRs $=f($ ExDS, ExDsP, ExR)

This is further transformed to an econometric model as follows:

$$
\log E_{x R s_{t}}=\beta+\beta_{1} \log E_{x D S}+\beta_{2} \log E_{x D s P}+\beta_{3} \log E_{x} R_{t}+\mu_{t}
$$

$\beta$ is the intercept of the model, $\beta_{1}-\beta_{3}$ are the coefficients of the independent indicators, $t$ is time series, and $\mu$ is the error term of the model.

ExRs is Nigeria's total reserves comprising holdings of monetary gold, special drawing rights, reserves of IMF members held by the IMF, and holdings of foreign exchange under the control of monetary authorities.

ExDS is total external debt. This is debt owed by Nigeria repayable in currency, goods, or services. Total external debt is the sum of public, publicly guaranteed, and private nonguaranteed long-term debt, use of IMF credit, and short-term debt. Short-term debt includes all debt having an original maturity of one year or less and interest in arrears on long-term debt.

ExDsP is total debt service payments. This is the sum of principal repayments and interest actually paid in currency, goods, or services on long-term debt, interest paid on short-term debt, and repayments (repurchases and charges).

ExR is foreign exchange rate. It is introduced as a control variable.

Further to this, the Augmented Dickey-Fuller test is employed to solidify the time series first before they are estimated at their orders of integration. This is to avoid spurious results and estimates. Furthermore, the Johanson co-integration test was employed to ascertain whether long run equilibrium relationship exist in the model or not. The existence of a single long run equilibrium relationship gives econometric credence to carry out the error correction process.

\section{Econometric Results}

5.1.Descriptive Statistics

Table 1 presents the summary descriptive statistics of the variables of the study.

Table-1. Descriptive statistics of the variables of the study

\begin{tabular}{c|c|c|c|c}
\hline Descriptive stat & ExRs & ExDS & ExDsP & ExR \\
\hline Mean & 9.911777 & 10.38712 & 9.289454 & 1.484203 \\
\hline Median & 9.874515 & 10.46272 & 9.270266 & 1.986346 \\
\hline Maximum & 10.72916 & 10.66500 & 9.944834 & 2.485840 \\
\hline Minimum & 8.969877 & 9.983057 & 8.695181 & -0.209220 \\
\hline Std. Dev. & 0.606889 & 0.172289 & 0.281641 & 0.858342 \\
\hline Skewness & -0.020680 & -0.721515 & 0.095888 & -0.763339 \\
\hline Kurtosis & 1.468697 & 2.490625 & 3.047192 & 2.270401 \\
\hline Jarque-Bera & 3.715451 & 3.707850 & 0.061758 & 4.533174 \\
\hline Probability & 0.156027 & 0.156621 & 0.969593 & 0.103665 \\
\hline Sum & 376.6475 & 394.7107 & 352.9992 & 56.39973 \\
\hline Sum Sq. Dev. & 13.62764 & 1.098290 & 2.934895 & 27.25981 \\
\hline Observations & 38 & 38 & 38 & 38 \\
\hline
\end{tabular}

The descriptive results indicate the observations are equal. The mean of the variables are; ExRs (9.911777), ExDS (10.38712), ExDsP (9.289454) and ExR (1.484203). Jarque-Bera statistics shows that all the variables of the study are normally distributed. The analyses further show that, aside ExDsP, all the other variables are negatively skewed.

The variability of returned indicated by the standard deviation statistics indicate as follows; ExRs (0.606889), $\operatorname{ExDS}(0.172289), \operatorname{ExDsP}(0.281641)$ and finally, ExR (0.858342). Comparatively, the values indicate that, all the variables are noticeable dispersed far below the mean and middle values.

\subsection{Augmented Dickey-Fuller Statistics}

Table 2 presents the summary unit root test statistics of the variables of the study.

Table-2. Summary augmented dickey-fuller test results.

\begin{tabular}{c|c|c|c}
\hline Variables & ADF statistics & Critical value @ 5\% & Decision \\
\hline ExRs & -5.496947 & -2.945842 & $\mathrm{I}(1)$ \\
\hline ExDS & -4.735518 & -2.945842 & $\mathrm{I}(1)$ \\
\hline ExDsP & -8.099317 & -2.945842 & $\mathrm{I}(1)$ \\
\hline ExR & -5.170243 & -2.945842 & $\mathrm{I}(1)$ \\
\hline
\end{tabular}

Note: The summary results indicate that all the variables are stationary at their first difference. This is symbolized as I(1).

\subsection{Johansen Co-integration Test Results}

Table 3 presents the Johansen cointegration test results of the study. 


\begin{tabular}{|c|c|c|c|c|}
\hline Hypothesized & & Trace & 0.05 & \\
\hline No. of $\mathrm{CE}(\mathrm{s})$ & Eigenvalue & Statistic & Critical Value & Prob.*** \\
\hline None $*$ & 0.613370 & 49.21195 & 47.85613 & 0.0371 \\
\hline At most 1 & 0.204982 & 15.00165 & 29.79707 & 0.7800 \\
\hline At most 2 & 0.134925 & 6.743598 & 15.49471 & 0.6076 \\
\hline At most 3 & 0.041498 & 1.525799 & 3.841466 & 0.2167 \\
\hline
\end{tabular}

The summary test results indicate the existence of long run equilibrium relationship in the model. Specifically, the summary test results indicate the existence of a single cointegrating relationship in the model. This invariably gives econometric credence to carry out the error correction process.

\subsection{Error Correction Results}

Table 4 presents the results of the error correction mechanism estimated using the least square technique.

Table-4. Error correction results

\begin{tabular}{l|c|c|c|c} 
Dependent Variable: D(EXRS) \\
\hline Variable & Coefficient & Std. Error & t-Statistic & Prob. \\
\hline $\mathrm{C}$ & 25.36673 & 3.099099 & 8.185195 & 0.0000 \\
\hline $\mathrm{D}(\mathrm{EXDS})$ & -1.633171 & 0.276432 & -5.908030 & 0.0000 \\
\hline $\mathrm{D}(\mathrm{EXDSP})$ & 0.049441 & 0.149019 & 0.331777 & 0.7426 \\
\hline $\mathrm{D}(\mathrm{EXR})$ & 0.679763 & 0.064195 & 10.58895 & 0.0000 \\
\hline $\mathrm{ECM}(-1)$ & -0.357739 & 0.113057 & -3.164225 & 0.0034 \\
\hline R-squared & 0.874184 & Mean dependent var & 9.943191 \\
\hline Adjusted R-squared & 0.855544 & S.D. dependent var & 0.595117 \\
\hline S.E. of regression & 0.226188 & Akaike info criterion & 0.007702 \\
\hline Sum squared resid & 1.381350 & Schwarz criterion & 0.236723 \\
\hline Log likelihood & 4.876764 & Hannan-Quinn criter. & 0.083616 \\
\hline F-statistic & 46.89958 & \multicolumn{5}{|l}{ Durbin-Watson stat } & 1.993854 \\
\hline Prob(F-statistic) & 0.000000 & \multicolumn{5}{l}{}
\end{tabular}

Table 4 x-rays the impact of external debt stock and external debt service payments on Nigeria's foreign exchange reserves. The adjusted coefficient of determinant indicated that $86 \%$ variation in the dependent variable is explained by the explanatory variables used in the study. This implies that the remaining $14 \%$ of variation is not captured in this study. The adjusted $\mathrm{R}^{2}$ coefficient further indicates that the model is well fitted. This is corroborated by the DW statistics of 1.993854 (which is approximately 2); indicating that there is no first order serial autocorrelation. Additionally, the indicator of the statistics of significance of the entire model (the Fisher's ratio) signaled that the model is statistically significant. Furthermore, the coefficient of the error correction term is negative. This implies that the model has capacity to adjust and return periodically to equilibrium. Specifically, the coefficient showed that there is a $36 \%$ slow speed of adjustment to equilibrium. This further indicates that the model is fit and adequate for the purpose of the study.

Furthermore, the explanatory variables aver as follows;

External debt stock (ExDs), which captures Nigeria's external debt portfolio to foreign financial institutions indicated that the external debt stock exert a negative impact on Nigeria's foreign exchange reserve portfolios. The measure of significance (t-statistics) also indicated it has a statistically significant impact on international reserves. This is indicative of the fact that, the coefficient of external debt stock is negative and the p-value is below the 5\% acceptable level of significance. This implies the external public debt stock has no bearing the accumulation of the international reserves of the country. This further avers that the external debt stock and international reserves have no direct link. This is contrary to economic theory which holds that exponential increase in the external debt stock would lead to the depletion of the reserves of a nation due to the fact that external settlements are sourced and paid from the international reserves of the sovereign nation.

External debt service payments (ExDsP), which captures the interest payable to internal financial institutions, indicated that the variable exerted a positive and statistically insignificant impact on the international reserves of Nigeria. This is indicative of the fact that, the coefficient of external debt service payment is positive and the pvalue is above the $5 \%$ tolerable level of significance. This goes to say that external debt service payments have an insignificant capacity to deplete the foreign exchange reserve holding of Nigeria. This implies that as the external debt service payments increase, maybe as a result of the accumulation of more external debt and or as a result of increase in international lending interest rate; so does it drain the international reserves of the nation at insignificant proportions. The finding by Anidiobu and Okolie (2016) is a close aproximation to the findings of this study. This closely follows economic theory which holds that exponential increase in the external debt servicing would lead to the depletion of the reserves of a nation due to the fact that external settlements are sourced and paid from the international reserves of the sovereign nation.

\section{Conclusion}

This study examines the impact of external debt and external debt servicing on the international reserves of Nigeria. Historical data spanning 1981 to 2018 was collated and analysed using the error correction mechanism as the unit of analyses and estimated employing the least square technique. The findings indicates that external debt stock exert a negative and statistically significant impact on Nigeria's foreign exchange reserve portfolios. This implies that external debt has no bearing on the foreign exchange reserve portfolios of the country. It further emerged that external debt service payments exert a positive but statistically insignificant impact on the 
international reserves of Nigeria. The study concludes that external debt stock and external debt service payments has no significant impact on the international reserve portfolios of Nigeria. The study recommends that, the fiscal managers of Nigeria should exercise cushion in external borrowing in order to ensure that spiraling external debt service payments does not deplete the international reserves of the country.

\section{References}

Abdullahi, M.M., N.A.B.A. Bakar and S.B. Hassan, 2015. Determining the macroeconomic factors of external debt accumulation in Nigeria: An ARDL bound test approach. Procedia-Social and Behavioral Sciences, 211: 745-752.Available at: https://doi.org/10.1016/j.sbspro.2015.11.098.

Akamobi, O.G. and O.T. Ugwunna, 2017. Determinants of foreign reserve in Nigeria. Journal of Economics and Sustainable Development, 8(20): 58-67.

Akpan, A.U., 2016. Foreign reserves accumulation and macroeconomic environment: The Nigerian experience (2004-2014). International Journal of Economics and Finance Studies, 8(1): 26-47.

Anidiobu, G.A. and P.I. Okolie, 2016. Responsiveness of foreign exchange rate to foreign debt: Evidence from Nigeria. International Journal of Arts Humanities and Social Sciences, 1(5): 11-20.

Asogwa, J.O., U.L. Onyekwelu and E. Okechukwu, 2018. Evaluation of the effect of federal government external debts and reserves on economic growth in Nigeria. Journal of Economics and Sustainable Development, 9(6): 34-44.

Ayadi, F.S. and F.O. Ayadi, 2008. The impact of external debt on economic growth: A comparative study of Nigeria and South Africa. Journal of Sustainable Development in Africa, 10(3): 234-264.

Chenery, H. and A. Strout, 1966. Foreign assistance and economic development. American Economic Review, $56(3): 679$ - 733.

Debt Management Office, 2019. Nigeria's external debt stock. Debt Management Office.

Draz, M.U. and F. Ahmad, 2015. External debts and exchange rates of oil-producing and non-oil-producing nations: Evidence from Nigeria and Pakistan. Journal of Advanced Management Science, 3(1): 8-12.

Espinoza, R. and P. Winant, 2014. A model of external debt and international reserves.

Essien, S.N., N. Agboegbulem, M.K. Mba and O.G. Onumonu, 2016. An empirical analysis of the macroeconomic impact of public debt in Nigeria. CBN Journal of Applied Statistics, 7(1): 125-145.

Eva, L., S.Y.L. Alvina and A. Mohammad, 2015. Macroeconomics determinants of external debt in Malaysia. International Journal of Economic Sciences, 4(4): 14-26.

Ito, H. and R.N. McCauley, 2019. Currency composition of foreign exchange reserves. Bank for International Settlement, Monetary and Economic Department. Basel : Bank for International Settlement. pp: 1-32.

Johansson, P., 2010. Debt relief, investment and growth. World Development, 38(9): 1204-1216.Available at: https://doi.org/10.1016/j.worlddev.2009.11.021.

Kouladoum, J.-C., 2018. External debts and real exchange rates in developing countries: Evidence from Chad. Université de Sarh, Munich Personal RePEc Archive. Munich: Université de Sarh. pp: 1-14.

Magazzino, C., L. Giolli and M. Mele, 2015. Wagner's law and peacock and Wiseman's displacement effect in European Union countries: A panel data study. International Journal of Economics and Financial Issues, 5(3): 812-819.

Mansour, L., 2013. International reserves versus external debts: Can international reserves avoid future financial crisis in indebted countries? GATE. Lyon: L'archive ouverte pluridisciplinaire HAL. pp: 1-32

Ndubuisi, P., 2017. Analysis of the impact of external debt on economic growth in an Emerging Economy: Evidence from Nigeria. African Research Review, 11(4): 156-173.Available at: https://doi.org/10.4314/afrrev.v11i4.13.

Nwachukwu, N.E., A.I. Ali, I.S. Abdullahi, M.A. Shettima, S.S. Zirra, B.S. Falade and M.J. Alenyi, 2016. Exchange rate and ex ternal reserves in Nigeria: A threshold cointegration analysis. CBN Journal of Applied Statistics, 7(1): 233-254.

Nwanne, T. and O. Eze, 2015. Assessing the effect of external debt servicing and receipt on exchange rate in Nigeria. International Journal of Economics and Finance, 7(9): 278-286.Available at: https://doi.org/10.5539/ijef.v7n9p278.

Olomola, P. and I. Ajayi, 2018. The determinants of international reserves in West African states. Global Journal of Human-Social Science, $18(4): 43-50$.

Onwuka, E. and H. Igwezea, 2014. Impact of external reserve and foreign debt on Naira exchange rate. Journal of International Academic Research for Multidisciplinary Impact Factor, 2(6): 416-423.

Oshikoya, W., 1989. Foreign borrowing, agricultural productivity, and the Nigerian economy: A macro-sectoral analysis. Journal of Policy Modeling, 1 1(4): 531-546.Available at: https://doi.org/10.1016/0161-8938(89)90003-3.

Osigwe, A., A. Okechukwu and T. Onoja, 2015. Modelling the determinants of foreign reserves in Nigeria. Developing Country Studies, 5(19): 72-77.

Rahaj, A.R., 2018. External debt and economic growth in Nigeria: An ARDL approach. Audoe, 14(4): 581-596.

Saheed, Z.S., I.E. Sani and B.O. Idakwoji, 2015. Impact of public external debt on exchange rate in Nigeria. International Finance and Banking, 2(1): 15-26.Available at: https://doi.org/10.5296/ifb.v2i1.7734.

Senibi, V., E. Oduntan, O. Uzoma, E. Senibi and A. Oluwaseun, 2016. Public debt and external reserve: The Nigerian experience (19812013). Economics Research International: 1-7.Available at: https://doi.org/10.1155/2016/1957017.

Soludo, C.C., 2013. The impact of external debt on economic growth: A comparative study of Nigeria and South Africa. Journal of Sustainable Development in Africa, 10(3): $55-59$.

Tule, M.K., E. Egbuna, J. Sagbamah, S. Abdusalam, O. Ogundele and A. Oduyemi, 2015. Determination of optimal foreign exchange reserves in Nigeria. Central Bank of Nigeria, Monetary Policy. Abuja: Central Bank of Nigeria.

Ugwuegbe, S.U., I. Okafor and C. Akarogbe, 2016. Effect of external borrowing and foreign aid on economic growth in Nigeria. International Journal of Academic Research in Business and Social Sciences, 6(4): 155-175.Available at: https://doi.org/10.6007/ijarbss/v6-i4/2087.

Yoshito, F., 2015. Wagner's law versus displacement effect. Munich Personal RePEc Archive. 